\title{
ANALIZA KONVERZACIJE I INTERAKCIJA U KASNOVEČERNJIM TELEVIZIJSKIM TOK ŠOU EMISIJAMA: PRIMERI SRPSKE I AMERIČKE EMISIJE
}

\begin{abstract}
$\mathrm{U}$ radu je prikazana primena analize konverzacije, metode koja ispituje ljudski govor u interakciji društvene svakodnevnice, na proučavanje diskursa govora-u-interakciji u kasnovečernjim tok šou televizijskim emisijama, koje su usredsređene na poznate goste i čiji je cilj da zabave gledaoce. Analiza je vršena komparativno, a za primere tok šou emisija uzeti su delovi intervjua s Novakom Đokovićem u srpskoj emisiji Veče sa Ivanom Ivanovićem i američkoj emisiji Conan, za koje je urađena transkripcija razgovora na osnovu video materijala dostupnog na internetu. Predstavljen je začetak analize konverzacije s njenom izvornom primenom u sociološkoj disciplini etnometodologiji i kasnije proširenje njenog delokruga na analizu diskursa i dati su njeni osnovni teorijski postulati uz neke od relevantnih pojmova. Poseban odeljak posvećen je tok šou televizijskom žanru, koji je određen kao deo javnog, odnosno medijskog diskursa, ali koji sadrži i elemente privatnog, odnosno svakodnevnog ili neobaveznog govora. Kao oblik intervjua, tok šou interakcija smatra se vidom institucionalnog govora, ali se ne zanemaruje njen neinstitucionalni karakter, koji se ogleda u interakciji primerenoj svakodnevnom govoru, poput one koju obavljamo s porodicom ili prijateljima. Stoga se prihvata klasifikacija polu-institucionalni govor.
\end{abstract}

Ključne reči: analiza konverzacije, diskurs, tok šou, govor-u-interakciji, polu-institucionalni govor

\section{Uvod}

Ovaj rad predstavlja kratku analizu konverzacije između voditelja i gosta u televizijskim humorističnim tok šou emisijama orijentisanim na razgovor/ćaskanje s poznatim ličnostima. Kako svaki tok šou podrazumeva govornu interakciju svojih učesnika, analiza je vršena pomoću analize

* C Čarnojevića 10a, Niš; e-mail: predrag.niketic@znrfak.ni.ac.rs 
konverzacije, istraživačke metode koja je usmerena ka ispitivanju svakodnevne govorne interakcije, ili tehnički govora-u-interakciji, kao aspekta šire društvene interakcije. Analizirani transkribovani delovi razgovora preuzeti su iz srpske tok šou emisije Veče sa Ivanom Ivanovićem i američke emisije Conan, pri čemu je, radi bolje poredivosti, u oba slučaja gost srpski teniser i globalno poznata ličnost u svetu sporta - Novak Đoković. Cilj analize je da se uoče eventualni razgovorni obrasci tipični za ovu vrstu interakcije i govorni mehanizmi kojima se voditelj i gost služe kako bi razgovor učinili zabavnim i informativnim za širi auditorijum, kojem su te emisije i namenjene. Takođe, pomenućemo i implikacije koje ova metodologija može imati po analizu diskursa tok šou interakcije, jedne od mnogobrojnih potkategorija medijskog diskursa. Pre same analize, naredna dva odeljka posvećena su teorijskom okviru analize konverzacije i glavnim odlikama gore navedenog tipa tok šou emisija.

\section{Analiza konverzacije - teorijski okvir}

Istorijski gledano, začeci analize konverzacije vezuju se za rad istaknutih američkih sociologa Harolda Garfinkela i Ervinga Goffmana iz pedesetih i šezdesetih godina prošlog veka. Garfinkelu se pripisuje uloga osnivača etnometodologije, pravca u sociologiji koji proučava ,zdravorazumske resurse, prakse i postupke kroz koje pripadnici društva proizvode i prepoznaju uzajamno razumljive predmete, događaje i tokove akcije“" (Liddicoat, 2007: 2; v. takođe Stević, 1997: 224; [prevod naš - P.N.]). To pretpostavlja postojanje društvenog ustrojstva i znanja o mehanizmima tog ustrojstva, koje poseduje svaki pripadnik društva i na osnovu kojeg usvaja i tumači svoju društvenu stvarnost. Ovo ustrojsvo zapravo je mentalni konstrukt svih društvenih aktera tokom njihove unutar-društvene interakcije i ne postoji kao nešto što je prethodno dato. Stoga se za etnometodologe društveno ustrojstvo objektivno, zapravo intersubjektivno ispoljava jedino kroz zajedničke vidove komunikacije (Ibid.: 2-3). S Goffmanom kreće ideja da pažnju treba posvetiti svakodnevnim interakcijskim instancama jer način na koji se pojedinci uključuju u svakodnevna dešavanja i situacije u društvu imaju veliki društveni značaj. Tako se svakodnevni govor vidi kao sistem pravila kojih se učesnici govorne interakcije nes- 
vesno pridržavaju, iako takva interakcija često može da deluje haotično, bez neposredno uočljivog ustrojstva. Takođe, govorenje sada prevazilazi ,čisto ${ }^{`}$ lingvističko tumačenje jer kao sastavni deo sadrži i nelingvističke elemente i pravila (Ibid.: 3-4; Heritage, 2005: 103).

Osnivačem analize konverzacije kao zasebnog pristupa smatra se sociolog Harvey Sacks koji je nizom predavanja od početka šezdesetih sve do sredine sedamdesetih godina XX veka (tj. svoje smrti) dao osnovne postulate analize konverzacije. U tome su mu umnogome pomogli sociolozi Emmanuel Schegloff i Gail Jefferson, koji su i posle Sacksove smrti nastavili i proširili njegov rad. Sacks je ovaj pristup razvio kao metodu proušavanja društvenog ustrojstva na osnovu konkretne svakodnevne razgovorne prakse. Naime, Sacksu je kao inspiracija poslužio korpus snimljenih telefonskih poziva upućenih Centru za sprečavanje samoubistava u Los Anđelesu, čijim je preslušavanjem uočio da osobe koje traže pomoć od centra često izbegavaju da se predstave i da to čine upotrebom različitih razgovornih mehanizama, npr. praveći se da nisu čuli pitanje ili ćuteći (Wooffitt, 2005: 2-3; Hutchby and Wooffitt, 2002: 18). Sacks je ustanovio da jezik u interakciji poseduje društvenu organizaciju i da se u toj mikro-organizaciji ogleda šire društveno ustrojstvo - u njoj postoje pravila koja govornici implicitno poznaju i kojih se pridržavaju kako bi preduzeli društvenu akciju u određenom kontekstu i da se ustrojstvo uspostavlja tek samim činom komunikacije, da učesnici sami teže održavanju ustrojstva tokom komunikacije, i da obrasci takvog ustrojstva važe za grupe govornika, ne samo za pojedince (Wooffitt, 2005: 8; Liddicoat, 2007: 4-5; v. takođe Heritage, 2005: 105). Iz lingvističke perspektive, treba napomenuti i to da se početak proučavanja svakodnevnog govora-u-interakciji može protumačiti i kao svojevrsna reakcija na, u to vreme dominantan, generativistički pristup proučavanja jezika, predvođen Noamom Chomskim, gde je govorna delatnost (engl. performance) bila zanemarena kao neuređena i ,iskvarena manifestacija jezičke sposobnosti (engl. competence) (v. Hutchby and Wooffitt, 2002: 22; Wooffitt, 2005: 19-20; Stević, 1997: 15). Uistinu, ako bismo se pridržavali načela gramatičnosti prema Chomskom, uočili bismo da govorni jezik svakodnevnice, pretočen u sintaksičke jedinice, obiluje negramatičnošću. Možemo ići toliko daleko da kažemo da je gramatičnost ovakvog jezika pre izuzetak nego standard. Međutim, Sacks je pronašao da čak i negramatičnost ispoljava izvesno ustrojstvo, ali samo u okviru stvarnih govornih situacija, a ne u okviru jezičke sposobnosti. 
Prema Sacksu, Schegloffu i Jeffersonovoj, u osnovi razgovora leži činjenica da se govornik upravlja prema slušaocu, koji zatim sâm postaje govornik i upravlja se prema prethodnom govorniku, koji zauzvrat postaje slušalac (Liddicoat, 2007: 5-6). Takvo uzajamno upravljanje sagovornika ima smisla jedino u okviru konteksta koji sagovornici dele. Kontekst može biti kako spoljašnji ili egzogeni, onaj u čijem okviru se interakcija obavlja, tako i unutrašnji ili endogeni ili intra-interakcijski, koji uspostavljaju sami sagovornici ali i koji zauzvrat određuje dalji tok govorne razmene (v. Stević, 1997: §4). Prema Heritageu, govor je oblikovan kontekstom (engl. context-shaped) ali govor i obnavlja kontekst (engl. context-renewing), jer se svaka sledeća instanca govora-u-interakciji zasniva na kontekstu prethodne istovremeno pružajući kontekst za narednu, što kontekst čini dinamičkim (Liddicoat, 2007: 7). I pored dinamičke prirode konteksta, razgovori se uvek odvijaju uspešno - uspešno u smislu poštovanja pravila govorne interakcije od strane oba (ili svih) sagovornika, a ne u smislu prihvatanja ili odobravanja nečega - što ukazuje na izraženu intersubjektivnost (engl. intersubjectivity), koja je jedan od osnovnih koncepata analize konverzacije. Još jedan osnovni koncept jeste društvena akcija (engl. social action), budući da svaki ljudski govor predstavlja vid akcije koju učesnici govorne interakcije prepoznaju kao smislenu i koju potom i sami vrše (Ibid.: 7). Upotrebom govornog jezika vrši se određena društvena akcija a ne puko pričanje ili opisivanje i analiza konverzacija usredsređena je na međusobno razumevanje akcije sagovornikā (Drew, 2005: 86). Akcija može biti jednostavno odazivanje ali i, npr. šala ili svađanje (Stević, 1997: 75). Pritom treba napraviti razliku između govornih činova iz teorije Austina (1962) i Searlea (1969), jer ,,[g]ovorni činovi izučavaju se kroz izdvojene, vansituacijske rečenice. S druge strane, analiza akcije vezuje se za njen neposredni, lokalni kontekst" (Stević, 1997: 76).

Još jedan temelj analize konverzacije jeste sekvencijalna organizacija (engl. sequential organization) konverzacije. Kako je analiza konverzacije deo pragmatike, osnovna jedinica konverzacije je iskaz (engl. utterance). Iskaz je akcijska struktura jer služi vršenju društveno relevantnih akcija, poput pozdrava, pitanja, naredbi i mnogih drugih (Ibid.: 22). Iskaz takođe gradi turnus (engl. turn) ili ,,mogućno upotpunjen, prozodijski izdvojen odlomak govorenja, kojem prethodi i kojem sledi promena govornika“ (Ibid.). Turnus u govoru-u-interakciji može sadržati jedan ili više 
iskaza. On takođe može da sadrži i minimalnu vokalizaciju, npr. $m h m$ kao znak odobravanja ili stavljanje do znanja sagovorniku da može da nastavi sa svojim iskazom, ali i elemente neverbalne komunikacije, npr. klimanje glavom. Osim iskaza, turnus mogu graditi i gramatičke jedinice konstrukcije turnusa (engl. turn-construction units ili TCUs) kao što su leksičke jedinice, sintagme ili rečenice ili fonetske realizacije, npr. intonacija, s tim da svaki TCU predstavlja akciju u kontekstu (Schegloff, 2007: 3-4). Turnus je značajan i kao komponenta temelja govora u interakciji, sistema reč-za-reč (engl. turn taking) ${ }^{1}$ koji podrazumeva naizmenične turnuse tokom govora, tj. kad jedan sagovornik završi svoj turnus, drugi počinje svoj i kada završi, prvi ponovo preuzima reč. Mesto gde se jedan turnus prekida a drugi počinje naziva se mesto relevantne tranzicije (MRT; engl. transition-relevance place (TRP)). Sistem reč-za-reč zasniva se na raspodelnoj komponenti turnusa (engl. turn distribution ili turn allocation component). Postoji skup pravila po kojima se turnus raspodeljuje na mesta relevantne tranzicije. Prvo pravilo glasi da sagovornik treba da započne svoj turnus na mestu na kojem ga prvi sagovornik bira da započne svoj turnus, ali da, ako do takvog izbora ne dođe, drugi sagovornik može da se samoizabere ili prvi sagovornik može da nastavi sa svojim turnusom. Drugo pravilo glasi da bez obzira na to koja je opcija iz prvog pravila primenjena, sve tri opcije ponovo dolaze u obzir na sledećem mestu relevantne tranzicije (Hutchby and Wooffitt, 2002: 49-50). Za sistem reč-za-reč odlikuje to da je sistem lokalnog upravljanja - raspodelu turnusa kontrolišu sagovornici (Stević, 1997: 36-37). Međutim, pri posmatranju MRT treba imati u vidu tranzicioni prostor (engl. transition space), koji Sacks, Schegloff i Jeffersonova određuju kao deo govora unutar kojeg može doći do tranzicije turnusa i koji počinje neposredno pre MRT-a a završava se neposredno posle (Liddicoat, 2007: 79). Ovo je idealizovan slučaj jer kod svakodnevnog govora tranzicioni prostor može biti duži ili kraći.

Za ovu razliku vezuju se pojmovi ćutanje i poklapanje. Ćutanje (engl. silence) predstavlja period negovorenja i svrha mu je da jasno odvoji iskaze ali i da nedvosmisleno ukaže sagovorniku da može početi sa svojim turnusom. Ukoliko se ćutanje javi unutar jednog turnusa, tj. intraturnusno, onda se to tretira kao pauza (engl. pause), a ukoliko se javi između dva tur-

1 Termin preuzet iz Stević (1997); takođe red govorenja, preuzimanje reči, smena/ smenjivanje govornika 
nusa, tj. interturnusno, tretira se kao zastoj (engl. gap) ili, ako je duže od tri sekunde, kao procep (engl. lapse) (prema Sacks, Schegloff i dr., 1974; cit. u Stević, 1997: 41). Pauza govorniku prvenstveno služi da pripremi nastavak turnusa, mada govornik često oseća da pauza može potrajati duže, što bi sagovorniku dalo lažan znak da je turnus završen, pa koristi brojne ispunjivače ili poštapalice (engl. fillers), npr. znaš, ovaj, mislim, pa, ili eto ili aktuelne znači i brate, vokalizacije ahm ili er, koje se po potrebi mogu produžiti, kao i nejezička sredstva, poput smeha ili čujnog uzdisaja/ izdisaja. Pauze u govoru mogu se tumačiti i kao kupovina vremena ili, prema Levinsonu (1983: 326), tajm-aut (engl. time out). Zastoji su redovna pojava u razgovoru dok procepi uzrokuju isprekidanost govora, što se može smatrati i odstupanjem od pravila raspodele turnusa. Poklapanje (engl. overlap) predstavlja simultani govor svih sagovornika koji počinje $\mathrm{u}$ tranzicionom prostoru i često je u svakodnevnom govoru-u-interakciji. Možemo ga protumačiti i kao rezultat intersubjektivnosti kada sledeći sagovornik započne svoj turnus pred kraj turnusa prvog sagovornika jer je značenje protumačio već na osnovu prethodnog dela iskaza prvog sagovornika. Ovo je tipično za pitanja i odgovore, kada se odgovara pre nego što je upitni iskaz završen jer je određen kontekstom:

S1: Bili smo na letovanju u Turskoj

$\mathrm{S} 2: \operatorname{Gd}[\mathrm{e}]$

S1: $\quad[\mathrm{K}]$ ušadasi

S2: Koliko du[go]

S1: $\quad[D] v e$ nedelje

Poklapanje koje počinje pre tranzicionog prostora naziva se prekidanje (engl. interruption), s tim što prekidanje može biti i svaki nagli početak turnusa pre nego što se prethodni završio, tj. upadanje u reč. Poklapanje se često javlja i kroz upotrebu pozadinskih akcija (engl. back-channel actions), gde spadaju minimalni odgovori ili žetoni (engl. tokens) poput $d a, \mathrm{mhm}$ i $a h a$, koje koristimo da govorniku stavimo do znanja da ga slušamo i pratimo.

Još jedan značajan mehanizam lokalnog upravljanja jeste popravka (engl. repair) (Hutchby and Wooffitt, 2002; Liddicoat, 2007; Stević, 1997), koja se ne odnosi isključivo na ispravljanje grešaka već i na razjašnjavanje nedoumica i dodavanje sadržaja koji nedostaje, odnosno na razrešenje problematičnih mesta u toku razgovora. Tako, na primer, 
možemo upotrebiti reč za koju smo svesni da je pogrešna ili da zaboravimo odgovarajuću reč i da je zatim sami ispravimo ili je se setimo. Na problem iz našeg turnusa može da nam ukaže i sagovornik i da mi onda obavimo popravku. Takođe, mi sagovorniku možemo da ukažemo na problem koji on zatim popravlja, a i sagovornik može i da nama ukaže na problem i da ga ispravi ako problem ne uspemo da prepoznamo. Problem u razgovoru, dakle, može biti bitan samo za pojedine ili za sve učesnike razgovora, kao što njega mogu biti svesni samo pojedini ili svi učesnici razgovora.

Prethodno pomenuta sekvencijalna organizacija govora proizilazi iz njenog vršenja društvene akcije (Stević, 1997: 72; Liddicoat, 2007: 105). Dva ili više turnusa čine sled (engl. sequence) i u njemu su akcijski raspodeljeni. Sled se sastoji iz najmanje dva turnusa i predstavlja akcijsku strukturu, pri čemu svaki turnus u sledu obavlja posebnu akciju. Neki tipovi sledova su pozdrav i otpozdrav, pozivanje i odazivanje, pitanje i odgovor, ili sledovi za otvaranje/zatvaranje razgovora. Postoje i sledovi koji se ugrađuju u tekući razgovorni blok: sled sa strane, uzgredni sled, i umetnuti sled (v. Stević, 1997: 73-75, 80-81). Za sledove i skevencijalnu organizaciju vezuju se mehanizmi lokalnog upravljanja upareni is$\mathrm{kazi}^{2}$ (engl. adjacency pairs). Upareni iskazi sastoje se od dva iskaza, pri čemu je drugi reakcija na prvi. Upareni iskazi očigledni su u slučajevima sledova pitanje/odgovor, poziv/odziv, ili pozdrav/otpozdrav. Za njih je karakteristično da se prvim turnusom zahteva i očekuje drugi, koji usled izvesnih okolnosti može i da izostane, ali takvo izostajanje ne može proći neopaženo. ${ }^{3}$ Određenim tipovima sleda ponekad prethodi deo kojim se taj sled uvodi, tzv. predsled (engl. pre-sequence) (Levinson, 1983). Predsled može biti oblika pitanje-odgovor, npr. Smem li nešto da te pitam / Naravno, ili nekog drugog oblika, npr. Ako mi dozvolite / Izvolite ili Izvinite/Recite (Izvinite kao čin skretanja pažnje a ne čin izvinjavanja). Blizinski parovi u govoru ne moraju nužno da budu iskazi: na pitanje često odgovaramo potvrdno klimanjem ili odrično odmahanjem glave; čak je moguće da ceo par bude čisto kinetički - podizanje glave nagore s dlanovima savijenim ka

2 Prema Steviću (1997); još i blizinski parovi i spojeni parovi

3 Setimo se da je Sacks inspiraciju za proučavanje govora dobio slušajući snimke telefonskih razgovora. Razvoj telefonske tehnologije doneo je identifikaciju pozivaoca što je uticalo i na sled otvaranja telefonskog razgovora pošto danas početni turnus nije nužno Halo kada je pozivalac unapred poznat. 
spolja može se protumačiti kao pitanje Kako si prošao? ili Kako je prošlo?, dok odgovor može biti podignut palac iz pesnice (Dobro), odmahivanje glavom (Loše), ili slezanje ramenima (Ne znam, videćemo).

Važna karakteristika govora-u-interakciji je i njegova preferencijalna organizacija (engl. preference organization), koja se odnosi na alternative za vršenje neke akcije pri govoru (Liddicoat, 2007: 110-111; Stević, 1997: 108). Najilustrativniji primer je akcija poziva (engl. invitation) koji može biti prihvaćen ili odbijen. Prihvatanje se smatra preferencijalnom (engl. preferred) delatnošću, dok se odbijanje smatra nepreferencijalnom (engl. dispreferred) delatnošću. Preferencijalnost je isključivo društveno uslovljena jer se prihvatanjem pospešuje društveni odnos a neprihvatanjem se on koči. Preferencijalni odgovori generalno se daju više spontano i s manje oklevanja dok se nepreferencijalni odgovori ne daju toliko brzo i sadrže duže turnuse, koji su obično prošireni ogradama poput zahvalnosti ili izvinjavanja. S društvenog aspekta, preferencijalna delatnost je neoznačena (engl. unmarked), dok je nepreferencijalna označena (engl. marked) jer je prihvatanje/slaganje, a ne odbijanje/neslaganje, podrazumevana i očekivana reakcija ${ }^{4}$ (Stević, 1997: 121).

Od odlika govora-u-interakciji treba još pomenuti predmet (engl. topic) i priču (engl. story telling).

Stević (1997: 123) navodi definiciju predmeta prema Keenanovoj i Schieffelinovoj (1976: 342-343): „Predmet diskursa je propozicija (ili neki njihov skup) što izražava neki sadržaj (ili skup sadržaja) na koji govornik ukazuje“. Predmet može biti određen propozicijskim sadržajem jednog ili više iskaza, odnosno kontekstom koji se aktivira, tj. neposredno realizuje pri razgovoru. Tipično, predmet se u razgovor uvodi posle sleda otvaranja razgovora a prekida se pre sleda zatvaranja. Predmeta tokom svakodnevnog govora-u-interakciji ima mnogo više nego u formalnoj govornoj interakciji, koja je po pravilu tematski ograničena. Ipak, predmet, kao jedan od elemenata organizacije govora smatra se manje bitnim od akcije koja se vrši (Liddicoat, 2007: 105). Liddicoat (Ibid.) daje primer pitanja Could you open the window? (Da li biste otvorili prozor) naglašavajući da je ovde neprikladno nastaviti razgovor u odnosu na predmet, tj. prozor, već da je očekivano da pitanju usledi akcija otvaranja prozora - pitanje se tumači kao poziv da se nešto uradi a ne kao priča o prozoru.

$4 \quad$ Upor. Schegloff (2007: 225-230) 
Priča (tu se može uvrstiti i pričanje viceva) predstavlja produženi turnus u interakciji i odstupa od sekvencijalnog ritma razgovora, odnosno remeti sistem reč-za-reč. Glavno pitanje vezano za učesnike razgovora jeste kako da obezbede prostor za produžetak turnusa kako sistem reč-za-reč omogućava razmenu turnusa prilikom prvog dostupnog mesta relevantne tranzicije (Liddicoat, 2007: 289). Jednostavnije, neophodno je staviti do znanja sagovorniku da će naredni turnus biti priča i da se razmena turnusa ne očekuje dok se priča ne završi - neophodno je obezbediti slušaoca. Priču, dakle, treba jasno uvesti u razgovor ali i jasno staviti do znanja slušaocu kada je priča gotova - ona mora da ima poentu. Dok traje priča, slušalac na nju može reagovati ćutanjem, pozadinskim akcijama poput $a h a, m h m, d a$, ali i da prekine priču i da je ne prihvati kao relevantnu za dati razgovor, naročito. Svakako, naratoru je najlakše kada slušalac sam inicira priču a legitimnost neke priče u razgovoru uslovljeno je time da li je priča slušaocu poznata ili nepoznata.

Na kraju ovog odeljka treba istaći da je analiza konverzacije izvorno, u svom etnometodološkom okrilju, bila usmerena na proučavanje snimljenog razgovornog materijala isključivo svakodnevnog, neobaveznog (engl. casual), spontanog govora-u-interakciji, da bi kasnije predmet interesovanja postala i formalna interakcija koja se vezuje za društvene institucije -govor u sudnici, na naučnim skupovima, na zvaničnim sastancima, u intervjuima, ceremonijama i u ostalim formalnim okruženjima razlikuju se od svakodnevnog neobaveznog govora i predstavljaju tzv. institucionalni govor, što govor svakodnevnice čini neinstitucionalnim govorom. Razlog za prvobitno opredeljenje analitičara konverzacije bila je ograničenost i specijalizovanost konteksta, koja govornicima ne daje ,slobodu kakvu imaju u svakodnevnom govoru i tako ih sputava u vršenju svih društvenih akcija koje im neobavezni govor omogućava. Ova podela pokazala se naročito bitnom za predmet našeg rada, diskurs tok šou interakcije, o čemu će više reči biti u odeljku koji sledi.

\section{Odlike televizijskog žanra „tok šou“}

Tok šou (talk show), kako se naziva u Sjedinjenim Američkim Državama, ili čet šou (chat show), kako se naziva u Ujedinjenom Kraljevst$\mathrm{vu}$, stari je format televizijske emisije koji se prvi put pojavio u SAD-u sredinom XX veka da bi šezdesetih godina prešao u Evropu, prvenstveno 
u Ujedinjeno Kraljevstvo, te se može reći da je on anglo-američka tvorevina. Prema Ilie (2001: 215), ,čini se da su i britanske i američke tok šou emisije proizašle kao javni produžetak privatne sfere, čime je premošćena razlika između javnog u medijima i privatnog kod gledalaca“. Svakako, postoje i razlike između američkih i britanskih tok šou emisija, ponajviše one kulturološki obeležene, pa ih ne treba posmatrati u okviru iste kategorije. U kontekstu društva uopšte, televizija je inače postala sastavni deo svakodnevnice svakog (ili makar većine) društvenog aktera. Tolson (2006: 7-8) ukazuje na to da se, prožimanjem društvene svakodnevnice, televizijsko emitovanje ispoljava i pozitivno i negativno. Sveprisutnost televizije čini je, prema Tolsonu, poput kakvog kućnog aparata koji se aktivira jednostavnim pritiskom na dugme. S druge strane, prevelika dostupnost i lakoća aktiviranja/deaktiviranja uslovljavaju televizije da po svaku cenu zadrže pažnju gledalaca (engl. buttonholing). Pa ipak, i ovo može imati pozitivan efekat ukoliko se televizije prilagode stvarnim potrebama gledalaca. Svaki tok šou u svojoj osnovi ima govor a njegova popularnost ogleda se u zadovoljstvu koje savremenim gledaocima pružaju različiti načini govora o različitim predmetima (Tolson, 2001: 3).

$\mathrm{U}$ vezi $\mathrm{s}$ istaknutim značajem konteksta pomenutim $\mathrm{u}$ prethodnom odeljku, može se dodati da razgovori koji se emituju na televiziji itekako utiču na svakodnevni govor (Tiittula and Nuolijärvi, 2000: 9; cit. u Danileiko 2005: 11) i društvene akcije koje se govorom vrše. Ipak, postoje dve suštinske razlike između svakodnevnog govora i govora u tok šou emisijama (Ibid.); na prvom mestu, svaka emisija vremenski je ograničena što ne važi za svakodnevnicu i drugo, tok šou postoji zbog publike/gledalaca i prema njima se određuje, bilo da su oni aktivni učesnici ili pasivni posmatrači, što ovaj vid interakcije čini specifičnim. U ovoj drugoj razlici ogleda se gorepomenuto premošćavanje razlika između javnog i privatnog, o čemu će više reči biti ispod. Kada je reč o sličnostima između ova dva tipa interakcije, tok šou interakcija sa svakodnevnom deli neformalan ton kao i nepredvidivost, stvaranje dinamičkog konteksta (česta i nagla promena predmeta) i povremeno odstupanje od ustrojstva formalnog intervjua pitanje/odgovor kada, na primer, gost usmerava tok interakcije (Ibid.: 17).

Kako bi se moglo i očekivati, do danas se promenilo pregršt različitih tipova tok šou formata, kako u anglo-američkim zemljama tako i u ostatku sveta, ali ono što se nikada nije promenilo jeste govorna interakcija 
između voditelja i gosta/gostiju ${ }^{5}$ kao temelj svake inkarnacije tok šou formata. I danas postoji mnoštvo različitih tipova tok šou emisija a neke od istaknutih razlika su, na primer, predmet koji se pokriva (zabavni ili informativni karakter), doba dana kada se emisija emituje (ujutru, preko dana ili uveče, odnosno morning, daytime, late night), učestalost emitovanja, nivo formalnosti, prisustvo publike i stepen učešća publike.

Donal Carbaugh (1988: 2-3) nudi podelu tok šou emisija na one koje su usredsređene na predmet diskusije (engl. issue-centered) i one koje su usredsređene na gosta kao (poznatu) ličnost (engl. personalitycentered). Tok šou emisije analizirane u ovom radu pripadaju drugoj grupi i karakteriše ih fokus na pružanje informacija o gostima i njihovom radu, pri čemu se često dotiče i njihov privatni život. U emisijama ovog tipa razgovor je neformalan, neobavezan i u mnogim elementima podseća na svakodnevni govor, tako da se često svodi na puko ćaskanje. Ne postoji jedan striktno predodređen predmet razgovora kao kod prve grupe emisija, već se predmeti smenjuju, uglavnom predmeti vezani za gosta inicirani od strane voditelja, ali neretko i od strane samog gosta, što ceo format razgovora čini krajnje nepredvidivim. Cilj takvog pristupa je da se publici pruže informacije o ličnostima i njihovim aktivnostima, ali i da im se pruži zabava i kod njih izazove smeh. U tom smislu, Ilie (2001: 211) predlaže naziv infotainment (slivenicu reči information i entertainment) za tok šou emisije. Ipak, ono što govor-u-interakciji u tok šou emisijama razlikuje od svakodnevne interakcije jeste vremenska ograničenost i institucionalno ustrojstvo koje leži u njenoj osnovi - na primer, voditelj je taj koji uvek otvara i zatvara razgovor.

U tok šou emisijama u čijem je centru ličnost, tj. gost, publika u studiju može se posmatrati kao treći učesnik u razgovoru jer aktivno utiče na tok razgovora, bilo smehom ili aplauzom, primoravajući voditelja i gosta da naprave zastoj ili procep pri čemu voditelj ili čuteći sačeka kraj aplauza ili započinje turnus ponavljanjem iskaza, dajući do znanja publici da završi svoj, uslovno rečeno, turnus. S druge strane, i voditelj i gost grade svoje turnuse tako da izazovu reakcije publike, prvi najčešće s namerom, a drugi više spontano. U takvom ,tročlanom“ razgovoru, u sistemu

$5 \quad$ Mada je uobičajeno da neke tok šou emisije imaju dva voditelja (najčešće žena i muškarac), danas se na američkim televizijama mogu videti i tok šou emisije u kojima ima čak četiri, pet, pa i šest voditeljki (The View, The Talk). 
reč-za-reč tranzicioni prostori variraju u trajanju i često se ne poštuju pa razgovori obiluju poklapanjima i prekidima. Treba naglasiti da aplauzi publike ponekad nisu spontani, već se publika navodi na aplauz svetlećim znakom na kojem je ispisana reč ,aplauz ${ }^{\circ}$, a koji obično kontroliše producent emisije. Ne treba zaboraviti ni publiku koja ove emisije gleda preko TV ekrana, koja ima znatno drugačiju perspektivu razgovora. Naime, tok šou emisije snimaju se pre emitovanja i razgovor između voditelja i gosta može početi ranije, a i delovi razgovora mogu biti izbačeni prilikom montaže, što publika koja gleda emisije na televiziji ne može da vidi (Danileiko, 2005: 12). Takođe, publika ispred TV ekrana izložena je reklamnim blokovima između različitih segmenata emisije. Bez obzira na to, ove emisije snimaju se i produciraju tako da TV gledaoci imaju utisak da se sve emituje uživo (Carnel, 2012: 25).

I voditelj i gost svesni su javne prirode svog razgovora, ali se taj razgovor i dalje odlikuje neformalnom, neobaveznom i ličnom notom i zasniva se na emotivnoj komponenti, pri čemu gost treba da se prikaže ne samo kao javna, već i kao privatna ličnost, što ga još više približava gledaocima, a što zauzvrat privlači gledaoce i povećava gledanost. Stoga se može zaključiti da su razgovori u tok šou emisijama deo javnog (medijskog) diskursa koji se umnogome oslanja na privatni diskurs. Formalno, tok šou interakcija vrsta je intervjua, a intervju predstavlja vid institucionalnog govora (institutional talk), koji se i formalno i sadržinski razlikuje od svakodnevnog neobaveznog govora. Heritage (2005: 106) daje tri osnovna elementa institucionalnog govora:

(1) Interakcija obično uključuje učesnike usmerene ka specifičnom cilju koji su vezani za svoje institucionalno relevantne identitete (npr. lekar i pacijent ili nastavnik i student);

(2) Interakcija podrazumeva posebna ograničenja po pitanju dozvoljenih doprinosa razgovoru;

(3) Interakcija se vezuje za inferencijalne okvire i procedure koje su karakteristične za date institucionalne kontekste.

Ako intervju posmatramo kroz ove elemente, to znači da intervju uključuje ispitivača i ispitanika kao institucionalno relevantne identitete, da je intervju ograničen formom ,pitanje ispitivača / odgovor ispitanika“, da će se relativno striktno poštovati sistem reč-za-reč, i da će se razgovarati isključivo o unapred određenom predmetu ili predmetima. Svakako, 
Heritage (Ibid.: 107) uočava izvesnu proizvoljnost pri pravljenju diskretnih kategorija svakodnevni i institucionalni govor jer se ljudi uglavnom služe istim resursima za oba vida interakcije. Tako je, na primer, moguće čuti elemente svakodnevnog govora u interakciji između lekara i pacijenta (Stević, 1997: 56). Pa ipak, postoje jasne empirijski određene razlike između svakodnevnog govora između prijatelja, poznanika, ili nepoznatih osoba $\mathrm{i}$ interakcije $\mathrm{u}$ školskoj učionici, $\mathrm{u}$ intervjuima $\mathrm{u}$ vestima, i u pravosuđu (Ibid.: 108). Tok šou interakcija svakako deli odlike intervjua (npr. gore pomenuto otvaranje i zatvaranje razgovora isključivo od strane voditelja), a Tolson (1991: 187) smatra da je tok šou ,institucionalno ,mešanje žanrova ${ }^{\circ}$ gde se tok šou intervju susreće sa stendap komedijom" [prevod naš - P.N.]. Ako se setimo da je u tok šou interakciji kršenje formalne i sadržinske norme intervjua pre pravilo nego izuzetak - gost postavlja pitanja voditelju, predmeti mogu i biti unapred određeni, ali se menjaju i prilagođavaju dinamičkom kontekstu koji se gradi tokom razgovora, a razgovor ima formu ćaskanja - videćemo da ona ima odlike i svakodnevnog i institucionalnog govora. S obzirom na ove odlike tok šou interakcije, Ilie (2001: 218) predlaže njeno određenje kao polu-institucionalni (engl. semi-institutional) diskurs, što mi prihvatamo kao upoterbljiv termin.

I Veče sa Ivanom Ivanovićem i Conan emituju se uveče, s tom razlikom da se srpska emisija emituje nešto ranije, za vreme udarnog termina (engl. prime time), od 21:15, dok američka pripada grupi tzv. late night tok šou emisija i emituje se u kasnovečernjem terminu, od 23 časa. Druga bitna razlika je učestalost emitovanja jer se Conan emituje svakog radnog dana sem petkom, dok se Veče emituje, svakog petka, s tim da efektivno traje sat i po nasuprot 40 minuta Conan-a. Srpski tok šou emituje se na TV stanici s nacionalnom frekvencijom dok se američki emituje na kablovskoj TV stanici, što znači da je srpski tok šou dostupan većem auditorijumu proporcionalno broju stanovnika teritorija koje emisije pokrivaju. Obe emisije neformalnog su karaktera, koji se odlikuje neobaveznim razgovorom (engl. casual conversation) ili ćaskanjem (engl. chat), i obe uključuju prisustvo publike, koja doprinos interakciji daje na primer kroz smeh ili aplauz. Uz to, obe emisije sadrže uvodni segment, tzv. monolog, koji je nalik na stendap komičarski nastup, jer se voditelji šaljivo osvrću na aktuelne društveno-političke teme. 
Sledi lista simbola transkripcije, sami transkripti, i srpski prevod srži razgovora na engleskom jeziku. Transkripcija je urađena za prvih nekoliko minuta oba razgovora te su u pitanju odlomci a ne celi razgovori. Napomena: Smeh/aplauz publike poklapa se sa jednim ili više turnusa oba govornika, što iz praktičnih razloga nije naznačeno u samim transkriptima.

\section{Simboli transkripcije}

(prema McIlvenny (2002: viii-ix), s modifikacijama)

A:

VELIKA SLOVA

Podvlačenje

${ }^{\circ}$ govor ${ }^{\circ}$

>govor $<$

"govor"

a::

$\dot{?}$

?

$\uparrow$ ili $\downarrow$

-

.hhh ili hhh

huh, ha, he

$(0.0)$
Trenutni govornik

(označen početnim velikim slovom imena)

Deo govora koji je glasniji od govora

koji ga okružuje

Naglašavanje u govoru

Deo govora koji je tiši od govora

koji ga okružuje

Deo govora koji je brži od govora

koji ga okružuje

Citiranje tuđeg govora

Dvotačka označava produžetak prethodnog zvuka; broj dvotački označava

trajanje produžetka

Opadajuća intonacija

Rastuća intonacija tipična za pitanja

Primetno povećanje ili smanjenje visine tona iskaza neposredno posle strelice Nagli prekid zvuka i zamuckivanje Čujni udisaj i izdisaj; broj slova h ukazuje na trajanje disanja

Čestice smeha

Govor kroz smeh

Cifre u zagradama predstavljaju trajanje pauze u sekundama u intervalima desetinki

(.) oo[ooo]

[ooo]oo
Mikropauza (ca. 0.2 sekunde ili manje)

Otvorena velika zagrada označava početak poklapanja;

zatvorena velika zagrada označava

kraj poklapanja 
ANALIZA KONVERZACIJE I INTERAKCIJA U KASNOVEČERNJIM TELEVIZIJSKIM ...

$=$

( )

((komentar))
Govor posle znaka jednakosti nadovezuje se na prethodni bez ikakve pauze Odeljak govora koji nije bilo moguće transkribovati Komentar transkriptora

Transkript 1: Ivan Ivanović (I) i Novak Đoković (N) (18. februar 2011.) 4m. 39s.

1 I: I: vreme je za našeg prvog i jedinog gosta večeras rekoše duhoviti ljudi odavno jedini Srbin koji pošteno živi od reketa.$h$ 个NOVAK ĐOKOVIĆ

2 ((aplauz publike, Ivan se pozdravlja s Novakom i obojica sedaju na svoje mesto))

3 ((Novak dodiruje neaktivan rekvizitni mikrofon na stolu))

4 I: Ne radi ne radi

$5 \mathrm{~N}$ : Ne radi ne radi

$6 \quad$ I: $=$ to je muzički primerak nešto

7 N: ( ) to je optička varka [( )]

8 I: [( ) te gotivi] ozbiljno te gotivi

9 ((aplauz publike traje, Novak ustaje i poklanja se))

10 I: I tako brate šta ima kod tebe jesi dobro $\uparrow$ ha ha ha ha ha ${ }^{\circ} \mathrm{ha}^{\circ}$

11 N: Odlično

12 I: Da $>$ dosta $\mathrm{si}<$ popularan ovde u Srbiji

$13 \mathbf{N}$ : h huh huh huh huh hh

14 I: Nole dobro veče dobro došao

15 N: ((klima glavom)) Hva[la]

16 I: $\quad[\mathrm{A}: \mathrm{m}]$ ne treba da ističem kolika mi je čast što si ti večeras er: moj gost er dve godine te nije bilo u emisijama er $\downarrow$ u Srbiji h i zaista si nam ulepšao veče stvarno hvala ti puno i u moje ime i u ime Prve srpske televizije

17 ((aplauz publike))

18 N: ((aplaudira publici)) Hvala hvala [bravo] bravo

19 I:

[zaista]

20 Mm dolaziš nam er:: (2.0) ((zastaje da bi se stišao aplauz publike)) dolaziš nam maltene pravo s australian oupena gde si počistio $\downarrow$ sve ove nesrećnike odučio ih [od] tenisa osvojio titulu .hh 
$21 \mathbf{N}:$

$[\mathrm{KH}]((\mathrm{smeh}))$

22 I: =er (.) kako se osećaš sada? 'ajde prvi put kad si osvojio pretpostavljam d- d- da ti mnogo onako luđe palo nego sada kakav je sad osećaj?

$23 \mathbf{N}:$ = pa ovako< pre svega o:vaj (.) moram da istaknem da je i meni zadovoljstvo i hvala tebi što si me pozvao u emisiju

24 ((aplauz publike))

25 I: uh huh [huh huh huh] huh

$26 \mathrm{~N}$ : [i:] zato što (.) ne (0.8) o:vaj zato što (.) zato što je tvoja emisija ubedljivo najbolja i: jedino nju gledam u Srbiji tako da svaka čast

27 ((aplauz publike))

28 I: mog' u pe[nziju] sad da i- [ha ha ha]

$29 \mathrm{~N}$ N [Ovde] [ovde si nas] ((pokazuje rukom na podijum za početni monolog u emisiji))

30 ovde si nas (0.5) ovde si nas pošteno nasmejao (.) [zaista ova:j]

31 I:

[ao hvala (.) hvala puno]

32 N: Ja sad sad možemo o:vaj bez problema da zaspimo .h er: [heh]

33 I:

[uh huh] huh huh

$34 \mathbf{N}$ : Ne (.) fenomenalno: ova:j sam počeo godinu zaista ne mogu da: ne mogu da poželim bolji start .h er:: međutim h er:: opet je samo početak sezone

35 I: Da [da]

36 N: [koja] traje (.) deset jedanes' meseci ovaj od dvanes' tako da .h moram da igram u kontinuitetu jako dobro ukoliko želim da (.) ostvarim jedan od (.) od zacrtanih ciljeva za ovu godinu a to je da (.) eventualno imam priliku da se dočepam prvog mesta he he he.$h h$

37 I: ((pruža palac nagore u znak odobravanja)) To mi re[ci molim te]

40 I: [B- b- b-] $\uparrow$ bilo je ova:j er: dosta priče o tvom mestu broj jedan i v- sigurno da svi mi ovde to želimo želiš ti pre svega .h ovaj $\uparrow$ Marej ti je dobar prijatelj i u svojoj biografiji je napisao da si nešto super čovek ${ }^{\circ} \mathrm{i}_{\text {to }}{ }^{\circ}$ je l' promenio mišljenje posle [ovog fa-?] 
$41 \mathrm{~N}:$

[Ma laže]

42 I: h jel' laže he he [he he] he [.HH(h) Ja da ti]

$43 \mathrm{~N}: \quad$ [To je] (.) marketinški trik [he he he he]

44 I: =kažem samo nešto ja sam gledao ovaj tvoj meč er:: finalni na Kopaoniku .h (.) niko ne skija divan dan idealno svi sede $u$ kafićima i gledaju meč

$45 \mathrm{~N}: \cdot \operatorname{hh}(\mathrm{h})$

46 I: $=\mathrm{i}:$ ono [što mene]

47 N: [Gde ste sedeli?]

48 I: Sedeli smo u Ski avenija Kopaonik tako se zove (.) [u sklopu Granda negde na ćošku]

49 N:

$[\mathrm{mhm} \mathrm{mhm}$ $\mathrm{mhm}]$

Aha

50 I: i svi su strašno vređali njegovu kevu koja je nosila onu [mrtvačku glavu]

$51 \mathrm{~N}$ :

$[\mathrm{A}::$ pa za]što?

52 I: Pa mi Srbi tako gledamo jel' [ $>$ znaš ti uopšte $<$ kako mi gledamo tenis ovde? jel' imaš informacije?]

$53 \mathrm{~N}$ :

[huh huh huh huh huh z(h)na.hhh Pretpostavljam]

54 =imam informacije znam [preko o:vaj] s- svojih [b- bliskih pri-]

55 I:

[,Jeste tvoj sin ua"] ((hrapavim glasom, pokazuje lakat (bras d'honneur) i plazi se uz ispuštanje detinjastog zvuka (blows a raspberry), prigušen smeh publike))

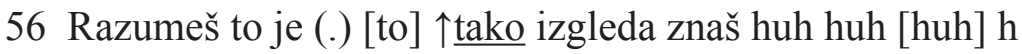

$57 \mathrm{~N}$ : [Da] [d- er]

58 da: drugim rečima da uh huh huh huh huh

59 I: Jel' ti imaš to na terenu ? jel' čuješ [d::]obacivanja $\downarrow$ [čak iz publike?]

$60 \mathrm{~N}$ :

[.hh]

[Ja:o

čujem] sve i svašta ovaj zaista: ako bih krenuo da ti pričam o tome do sutra bi' mog'o da ti ispričavam ovaj situacije koje smo doživljavali .h doživljavali ovaj .hh svi r- svi teniseri na h na gren slemu ovih godina i pošto $\downarrow$ dobro mis- mis'im mi smo svesni da: 
da ti ljudi koji žive (.) pogotovo u Australiji (.) o:vaj jedva čekaju priliku da vide neke od- neke od naših er profesionalnih sportista kako bi imali priliku da ih podržavaju jelte $\mathrm{i}$

61 I: =To im je praktično jedini: ono kontakt sa [otadžbinom je 1' tako?]

$62 \mathrm{~N}$ :

[Pa:: jeste] jeste i mi smo svesni toga $i$ onda pokušavamo na neki način da: da razumemo (.) ovaj njih ali to su komentari tipa .hh ,'Ajmo na pivo posle 'ajde: (.) er: (.) piški mi se kaki mi se 'ajde: (.) 个'ajde probudi se malo nemoj više da grešiš zašto u mrežu .h 'ajde malo skoskoncentrisanije“ i onda za vreme $\mathrm{f}(\mathrm{h})$ inala .h o:vaj er za vreme $>$ finala austrelian oupena ove godine $<$.h bila je jedna žena (.) sedela je ja mislim drugom redu odmah iza klupe (.) i svaki put kada (.) kada bih seo između o:v- između gemova ona bi mi .h nešto dobacila

63 I: Huh

64 N: =samo na našem jeziku i sad mis'm svi su je gledali i [ona pošto]

65 I:

$[>$ Šta šta $<$ je vikala?] šta je vi-

66 N: =PA VIKALA JE pa vikala je nešto poput er: (.), ,'Ajde malo se skoncentriši 'ajde malo brže malo [nogama nogama $>$ ne ne $<$ ne] pa NE PA NE

67 I: [Što dobro ti je išlo šta šta je bilo sporno? ono] ha ha ha huh

68 ((aplauz publike))

$69 \mathbf{N}:=$ ja j-j(h)a je po[štujem]

70 I: $\quad$ [huh huh huh]

$71 \mathbf{N}:=$ ja joj kažem svaka čast er [to je]

72 I: [uh huh huh]

$73 \mathbf{N}$ : =njena zasluga bila zaš’o sam tako dobro odigrao huh huh

$74 \mathbf{I}:=a$ ona te bodrila

75 ((aplauz publike))

Transkript 2: Conan O’Brajen (C) i Novak Đoković (N) (3. avgust 2011.) $3 \mathrm{~m} .26 \mathrm{~s}$. 
$1 \mathbf{C}:$ My next guest to $\uparrow$ night is the number one ranked tennis player in the wo:rld and thee two thousand eleven Wimbledon champion (.) please welcome the pride of Serbia Novak $\uparrow \underline{\text { Djokovic }}$

2 ((aplauz i ovacije publike, Novak se rukuje s Conanom, drugom gošćom i Conanovim pomoćnikom (sidekick), koji ne učestvuju u razgovoru, i svi sedaju na svoje mesto))

3 C: how are you? thanks for [being here]

$4 \mathbf{N}$ : [great] thanks for having me

5 C: Uh (.) very cool $>$ first of all $<$ congratulations what an achievement you are the number one player in the world has it sunk in yet?

6 N: Wow uh:: it takes a while [you know] uh::: [it's a]

7 C:

[Yeah]

[Did] I just tell you that for the first time? ha ha

$8 \mathbf{N}$ : =ha ha ha ha

9 ((smeh publike))

$10 \mathrm{C}: \mathrm{Wh} \uparrow a::[\mathrm{t}$ ?]

$11 \mathrm{~N}$ : [It] was like for two hundred fifty seven time that I heard it here [that ( ) haha]

$12 \mathrm{C}$ :

[Yeah yeah]

13 =it's it's no it's it's just gotta be: [uh]

$14 \mathrm{~N}$ : $\quad[\mathrm{No}]>$ it's it's it's $<$ really incredible I mean if you're working for something all your life an' you're (0.5) determined to do that you're dedicated hundred percent to the sport in twenty years and after twenty years you (.) you're there it's it's incredible feeling

15 C: $>$ Now now $<$ in in Serbia >and I'm not tryin' to embarrass you $<$ but you are a $\downarrow$ god $(0.5)$ in Serbia your face is on .h $\underline{T}$ shirts (.) posters (.) .h uh: uh you >do you ever g- when you go ba- when you go back home do you< ever get sick of seein' your own face? it's lit'rally (.) [ $\uparrow$ everywhere]

$16 \mathbf{N}$ : [yeah yeah]

17 =the the thee uh (.) even my family like an' and friends and everybody's complaining that y'know

18 I'm I'm jumping out of the fridge (.) for them like 
19 ((smeh publike))

$20 \mathbf{N}$ : =" $\uparrow$ oh:: here's a $\downarrow$ I'm going and walking in the night and I just wanna grab a (.) a beer $\uparrow$ oh: there's Novak on the beer yeah"

21 ((smeh publike))

$22 \mathbf{C}$ : =ha ha ha ha [ha ha]

$23 \mathrm{~N}$ : [and you] having a coffee "oh he's there in the sugar" [yeah I justa]

$24 \mathrm{C}$ :

25 ((smeh publike))

[Yeah yeah]

$26 \mathrm{C}:={ }^{\circ}$ he he ${ }^{\circ}$

$27 \mathbf{N}:=[$ yeah]

28 C: $=$ [huh huh] [(h)you're b(h)eing $]$

29 N: [hh huh]

30 C: Well

$31 \mathbf{N}$ : = But listen you can be famous too if you just dress up as a tennis player there. I mean you can be $(0.5)$ quite famous in Serbia (.) why don't you come (.) y'know stop by?

32 C: Aren’t I $\downarrow$ already quite famous [in Serbia?]

33 ((smeh publike))

34 N:

[you know what] listen (.) you are alrea[dy]

$35 \mathrm{C}$ :

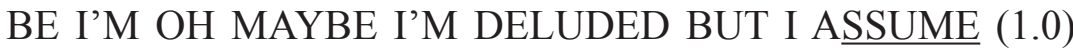
THAT I'M A GOLDEN GOD in Serbia

36 ((smeh publike))

37 N: Listen ((hvata Conanov ručni zglob kao da ga smiruje)) I got you I got you something ((seže za nečim ispod naslona fotelje)) this is gonna help you out to be famous there ((vadi minijaturni teniski reket i pruža ga Conanu))

38 C: $\uparrow$ Oh::: ((zamahuje reketom ispred sebe gledajući prvo u kameru a zatim u publiku)) what is th-

39 ((smeh publike))

40 N: You know (.) you should (.) you should learn how to play with that and then the uh:

$41=$ [you know if you're]

$42 \mathrm{C}:=[$ and then pro]gressively work to a bigger ra[cket]

43 N:

[exactly] 
$44=$ If [you're] real deal we're gonna speak about a bigger one

45 C: [Wow]

Now wait a minute (.) is my show on? $=$ I'm gonna make this about me for a second

$46 \mathrm{~N}:=[$ yeah go ahead]

$47 \mathrm{C}:=[\mathrm{coz}]$ that's what I $\downarrow$ do $[\mathrm{a}: \mathrm{hm}]$

$48 \mathrm{~N}$ [hahaha]

$49 \mathrm{C}$ : Is Is this show on? $\mathrm{d}$ - are is is [this am I even on] in Serbia [before]

$50 \mathrm{~N}$ :

[个yeah yeah yeah] [they love you]

$51=$ [they love you]

52 C: $=$ [Really?]

$53 \mathrm{~N}$ : Yeah they $\uparrow$ do

$54 \mathrm{C}$ : Do they have their own late night host?

$55 \mathrm{~N}$ : Yeah (.) yeah they do they do have one actually 'is his name is Ivan Ivanovich and it's like night [with I-]

$56 \mathrm{C}$ : [EE]VAN EEVANOVICH?

$57 \mathrm{~N}:=$ Exactly

58 C: [And it's]

59 N: [He's] he's trying to impersonate you but he (0.5) 'e like he he's like half of your size so 'e has to work on that ${ }^{\circ}$ a bit ${ }^{\circ}$ ((rukom pokazuje visinu Ivana Ivanovića))

60 ((smeh publike))

61 C: There's a guy named $\uparrow$ Eivan Eivanovich? Eevan or [Iv-]

$62 \mathrm{~N}:$

[Yes] Ivan

$63 \mathrm{C}:$ I hate that guy

64 N: ((glasno se smeje))

65 ((smeh publike))

$66 \mathrm{C}$ : Is he wearing like a red wig ((prelazi obema rukama preko čela)) or anything and jumping around ((pravi se da skače i maše rukama dok sedi)) like an idiot?

67 N: Uh hu::- ((okleva, implicirajući odričan odgovor))

68 C: Ah: good [I win]

$69 \mathrm{~N}: \quad$ [Not yet] $\quad$ (glasno se smeje) $)$

70 ((smeh publike)) 
71 C: $>$ Wait a minute $<$ (.) I lose uh:

$72 \mathbf{N}:=$ Huh huh

$73 \mathrm{C}$ : This is amazing ((uzima tabak poštanskih marki s drugog kraja stola)) I think you're the first guest I maybe I've ever $\uparrow$ talked to who has 'is own stamp (.) that's absolutely incredible you have your own (0.5) ((kamera zumira marke)) $>$ look at these stamps over here $<$

74 ((aplauz i ovacije publike))

75 N: You ah: (.) maybe (.) y'know you can take the stamp you can lick me and put me wherever you like

76 ((smeh publike))

77 N: or place 'em here ((pokazuje na površinu stola))

78 C: You are on my list

79 ((svi se smeju))

$80 \mathrm{C}$ : It's kind of a crazy list uh::

81 ((smeh publike))

\section{Prevod Transkripta 2}

C: Moj sledeći gost večeras je najbolje rangirani teniser na svetu i pobednik Vimbldona 2011. godine. Molim vas, pozdravite ponos Srbije Novak Đoković!

C: Kako si? Dobro došao.

N: Odlično, bolje vas našao.

C: Super. Pre svega, čestitke, kakav uspeh, prvi si teniser sveta. Jesi li svestan toga?

$\mathbf{N}$ : Potrebno je izvesno vreme, znate, to je...

C: Da, da li si ovo tek sada prvi put čuo od mene?

C: Molim?!

N: Ovde sam to čuo, ono, po 257. put...

C: Da, to mora da je...

$\mathbf{N}$ : Ne, to je zaista neverovatno, mislim, ako radiš za nešto celog života i odlučan si u tome, stopostotno si posvećen sportu tokom 20 godina i posle 20 godina si tu gde jesi... osećaj je neverovatan.

C: U Srbiji - ne želim da te postidim - u Srbiji si bog, tvoje lice je na majicama, na posterima... da li ti ikada dosadi da vidiš sopstveni lik kada 
se vratiš kući jer on je bukvalno svuda?

N: Da, čak i moja porodica, i prijatelji, i svi ostali žale se kako iskačem iz frižidera, oni, recimo, kažu „Oh, evo ga... izlazim i šetam noću i samo hoću da popijem pivo, ali eto Novaka na pivu, da..."

N: Ili ako se pije kafa: „Oh, evo ga u šećeru“.

C: Da, da.

$\mathbf{N}$ : Ali slušajte, i Vi tamo možete biti poznati ako se obučete kao teniser, mislim, možete biti prilično poznati u Srbiji. Zašto ne dođete, ono, da svratite? Znate šta? Slušajte, Vi ste već...

C: Možda sam u zabludi, ali pretpostavljam da sam zlatni bog u Srbiji!

N: Slušajte, doneo sam Vam nešto. Ovo će Vam pomoći da tamo budete poznati.

C: Šta je o-

$\mathbf{N}$ : Znate, trebalo bni da naučite da igrate njime, a zatim, znate, ako budete...

C: A da zatim postepeno napredujem do većeg reketa?

N: Tako je. Ako se pokažete, možemo da pričamo o većem reketu.

C: Stani malo! Da li se moja emisija tamo prikazuje? Sada ću malo da stavim sebe u centar pažnje.

N: Da, slobodno.

C: Jer je to ono što inače radim. Da li se ova emisija uopšte prikazuje u Srbiji?

N: Da, da, da, tamo Vas mnogo vole.

C: Zaista?

N: Zaista.

C: Da li tamo imaju svog voditelja kasnovečernje emisije?

N: Da, zapravo imaju, zove se Ivan Ivanović i to je kao veče sa...

C: Ivan Ivanović?!

N: Tako je.

C: I to je...

N: Pokušava da Vas imitira ali je, ono, duplo manji od Vas tako da mora malo da radi na tome.

C: Dakle, tamo postoji tip koji se zove Ajvan Ajvanović? Ivan ili...?

N: Da, Ivan.

C: Mrzim tog tipa! Nosi li crvenu periku ili tako nešto i skače li unaokolo poput nekog idiota? 
C: Dobro je! Pobedio sam.

N: Ne još.

C: Čekaj malo... ipak sam izgubio.

C: Ovo je zapanjujuće. Mislim da si mi ti možda prvi gost s kojim sam razgovarao koji ima sopstvenu poštansku marku, to je potpuno neverovatno, imaš svoju... pogledajte ove marke.

$\mathbf{N}$ : Vi možda, znate, možete da uzmete marku, da me liznete i da me zalepite gde god želite... ili da ih stavite ovde.

C: Na mom si spisku... a to je prilično šašav spisak.

\section{Analiza transkripata}

Referentna mesta u transkriptima data su na sledeći način - T1:25, gde se T1 odnosi na prvi transkript a broj posle dvotačke na broj reda/ redova u transkriptu. Analiza će biti vršena putem jukstapozicije tokova dva razgovora.

Iako je razgovor T1 više od jednog minuta duži od T2, T2 sadrži više razmenjenih turnusa, što ukazuje na dinamičniji i sabijeniji tok razgovora američke emisije. Ovo se može objasniti vremenskim ograničenjem, koje je izraženije u emisiji Conan, dok Veče traje duže i razgovor sa svakim gostom duže traje. Tome svakako doprinosi i činjenica da je u T1 Novak Đoković jedini gost te epizode (T1:1).

Oba voditelja pridržavaju se tok šou konvencije predstavljanja gosta publici u studiju i TV gledaocima i obojica koriste naglašavanje prilikom izgovaranja imena gosta (T1:1, T2:1). Ivan Ivanović (u daljem tekstu Ivan) u predstavljanje ubacuje i šalu koristeći dvoznačnost reči reket. Primećuje se da prilikom predstavljanja Conan O'Brien (u daljem tekstu Conan) pruža auditorijumu (sva publika, i studijska i TV gledaoci) više početnih informacija o gostu, uključujući i onu da je ponos Srbije. Ovde je bitno deljeno znanje o Novaku - Ivan i njegov auditorijum već znaju dosta o gostu, dok u Americi jedan deo auditorijuma sigurno ne zna ko je gost i čime se bavi.

Konvencionalni upareni iskazi pitanje/odgovor prilikom otvaranja razgovora prisutni su u oba razgovora, s tom razlikom da u T2 prvi turnus sleda otvaranja kreće odmah (T2:3-4), dok u T1 počinje nešto kasnije (T1:10-11). T1 zapravo sadrži dva predsleda: u prvom Ivan i No- 
vak razmenjuju nekoliko gde je predmet rekvizitni mikrofon na stolu a u drugom Novak reaguje na aplauz publike, koji traje sve to vreme, tako što ustaje i poklanja se poput glumca. Ivan već na samom početku (T1:10) koristi iskaz primereniji svakodnevnom govoru s kolokvijalnim načinom obraćanja brate i tako izlazi iz domena institucionalnog. Upotreba ove reči može se protumačiti i kao antiteza dugačkom aplauzu i Novakovom statusu velike zvezde, s kojom voditelj ima izrazito familijaran odnos.

Conan odmah posle kratkog sleda otvaranja uvodi prvi predmet razgovora (T2:5), Novakovo osvojeno prvo mesto na ATP listi i njegov lični stav o toj činjenici (T2:5-14). U ovom sledu Novak počinje da odgovara na pitanje, i Conan mu stavlja do znanja da mu je posvetio pažnju žetonom yeah (T2:7), međutim Novak produžava ispunjivač (T2:6), što Conan oseća kao tranzicijski prostor i prekida ga s poklapanjem da bi započeo turnus kojim počinje umetnuti sled (T2:7-12), da bi Novak konačno odgovorio na pitanje svojim turnusom T2:14.

U T1 Ivan znatno proširuje sled otvaranja (T1:10-19) kako bi istakao značaj Novakovog prisustva, na šta reaguje i publika a zauzvrat i Novak koji aplaudira publici uz pohvalu bravo. Interakcije gostiju s publikom, makar i neverbalne, nisu neuobičajene u ovom TV formatu. U odlomku T2 takve interakcije nije bilo. Prvi predmet razgovora Ivan uvodi u T1:20,22, ali Novak je taj koji sada krši konvenciju tako što ne odgovara na pitanje već započinje novi sled (T1:23-33). Posmatrajući lokalni kontekst, ovaj umetnuti sled možemo tumačiti i kao proširenje sleda koji je završen u T1:16. Odgovor na pitanje iz T1:22 Novak daje tek u T1:34,36.

Conan uvodi drugi predmet razgovora (T2:15-30), Novakovu popularnost u Srbiji, pri čemu se Novak služi izrazom iskočiti iz frižidera (T2:18), što je noviji srspski frazeologizam, koji označava nečiju preteranu popularnost a kojeg nema u engleskom jeziku. Pa ipak, smeh publike ukazuje na to da je idiomatsko značenje uspešno međujezički preneto. U T2:31 uočavamo narušavanje konvencije intervjua jer se sada menjaju uloge i Novak postavlja pitanje Conanu, menjajući predmet razgovora $\mathrm{u}$ - samog Conana. Conan, pak, na pitanje odgovara pitanjem i ne dopušta Novaku da odgovori dajući glasan ironični komentar i pretvarajući se da je uznemiren (T2:32-35). Novak koristi ovaj kontekst da mu uruči poklon koji mu je spremio, minijaturni reket, posle čega Conan nakratko napušta interakciju s Novakom i okreće se ka kameri, tj. TV gledaocima a zatim i 
prema publici u studiju. Sve do T2:45 Novak je taj koji igra ulogu voditelja. Ivan $\mathrm{u}$ jednom produženom turnusu zaokružuje tekući predmet $\mathrm{i}$ započinje novi (T1:40). Novak umesto odgovora na pitanje šaljivo odbacuje Ivanovu propoziciju kao laž (T1:41), dok Ivan proširuje predmet „Endi Marej“ uvođenjem kratkog narativnog sleda, odnosno anegdote, što je očito iz upotrebe pripovedačkog prezenta (T1:44). Novak ovom prilikom ne poštuje pravila sistema reč-za-reč, već van mesta relevantne tranzicije umeće svoje pitanje (T1:47), ali zatim koristi pozadinsku akciju tokom nastavka anegdote (T1:49).

Posle kraće zamene uloga, Conan se vraća u ulogu voditelja, čak do te mere da sebe, tj. svoj tok šou određuje kao sledeći predmet (T2:45). Ovaj deo (T2:49-57) predstavlja sled s najviše uparenih iskaza pitanje/odgovor. Sticajem okolnosti, voditelj Ivan Ivanović postaje sledeći predmet (T2:55-72). I Conan i Novak trude se da u ovom sledu daju šaljiv doprinos interakciji, Novak pokazujući rukom Ivanovu visinu, a Conan iskazom mrzim tog tipa i auto-parodijom.

Novakovo pitanje u T1:51 pokreće novi predmet, gledanje tenisa u Srbiji s emotivnim nabojem. Ivan gestikulacijom i promenom boje glasa oponaša hipotetičkog gledaoca tenisa (T1:55). T1:59 uvodi još jedan predmet, dobacivanje iz publike za vreme meča (T1:59-75), koji Novak razvija nešto dužom narativnom strukturom (T1:60, 62), a koja je isečena jedino Ivanovim nadovezujućim turnusom (T1:61). Kada se završi drugi Novakov duži turnus, sistem reč-za-reč vraća se na prethodni ritam kraćih turnusa.

Poslednji predmet u T2 odlomku su poštanske marke s Novakovim likom (T2:73-81), a Conan ovde ponovo komunicira s auditorijumom skretajući im pažnju da pogledaju markice koje je kamera prethodno zumirala (T2:73). Zanimljivo je da se Novak ovde šali, pomalo atipično za dotadašnji tok interakcije, upotrebom igre reči sa seksualnom konotacijom možete [... ] da me liznete, ${ }^{6}$ pritom misleći na marku. Conan prihvata šalu i razvija je poslednjim turnusima u odlomku.

Iz priloženog se vidi da je u obema interakcijama bilo više predmeta, koje je uvodio i voditelj i gost. Predmeti se, nasuprot formalnom intervjuu, uvode mehanizmima koji odlikuju svakodnevni govor. Ivan (T1) koristi ispunjivače $m m$, er (20), i ovaj (40), ali i neformalno postavljena

$6 \quad$ Novakovo obraćanje Conanu preveli smo oblikom persiranja s obzirom na to da je ovo Novaku bilo prvo gostovanje kod Conana i da je Conan u vreme snimanja emisije bio dvostruko stariji od njega. 
pitanja oblikom jel' $(52,59)$. Conan (T2) takođe koristi ispunjivače, poput $u h^{7}(5)$ i now $(15,45)$, neobeleženi upitni oblik (54), ali i rečenični iskaz this is amazing (73). Kod Conana, Novak pri zameni uloga uvodi predmet veznikom but (ali) (T2:31).

U T1 sagovornici ne koriste često pozadinske akcije kojima ukazuju sagovorniku da ga prate; kada ih koriste, to su da (35), mhm i aha (49). Sličan je slučaj i u T2, gde Conan korsiti samo yeah (da, jeste) $(7,12,24)$.

Mikropauze i zastoji zastupljeni su u oba razgovora (preko 20), i najčešće se vezuju za govor gosta, koji pravi najviše pauza i to u turnusima srednje i veće dužine. Primetno je da Conan koristi mikropauze i zastoje kao mehanizam isticanja onoga što sledi pauzu $(\mathrm{T} 2: 1,15)$ ili onoga što prethodi pauzi (T2:15, 35, 71). Kod Ivana ovakva upotreba ćutanja nije uočena već se ona javljala više spontano.

Oba razgovora obiluju poklapanjima: bez prekidanja (npr. T1:50, 51; $\mathrm{T} 2: 3,4)$, sa prekidanjem $(\mathrm{T} 1: 64,65 ; \mathrm{T} 2: 34,35)$, ili sa simultanim govorom $(\mathrm{T} 1: 52,53)$, što ukazuje na spontanost razgovora i izraženo odstupanje od institucionalnog govora intervjua. Štaviše, poklapanja u ovim primerima ima toliko da ih možemo tumačiti kao podrazumevanu, neobeleženu odliku tok šou žanra kao vida polu-institucionalnog govora.

Od poštapalica u T1 najzastupljenija je ovaj, naročito kod Novaka $(26,34,36,54,60,62)$. Kod Conana nije primećene upotreba poštapalica, ali zato jeste kod Novaka (T2), prvenstveno you know (znaš) $(17,31,40$, 75) i like (ono, ono kao) $(11,17,18)$.

Treba pomenuti drastičnu razliku u broju čujnih udisaja/izdisaja između dva razgovora. Naime, u T1 slučajeva čujnog disanja ima čak 25, dok ih u T2 ima svega dva (samo Conan). Ovo se može objasniti pomoću trajanja razgovora: u emisiji Conan intervju s jednim gostom retko prelazi 10 minuta, dok u emisiji Veče sa Ivanom Ivanovićem razgovor s gostom može da traje i čitavih sat vremena. Stoga je kod Conana primetna brža razmena turnusa, koji su samim tim kraći pa je za proizvodnju govora dovoljan jedan izdisaj. Kod Ivana ima više dužih turnusa i ponekad je neophodno uzeti vazduh pre govora i izbaciti višak. U čujnim udisajima/ izdisajima prednjači Novak u odnosu na Ivana.

Kraći turnusi koji se brzo razmenjuju u T2 impliciraju da se u takvom toku interakcije ne može pričati priča, dok je u T1 to izvodljivo, što se vidi

$7 \quad E r$ u srpskom transkriptu i $u h$ u engleskom transkriptu označavaju isti zvuk. U srpskom transkriptu $u h$ je čestica smeha. 
iz Novakove priče o iskustvima s dobacivanjem iz publike (T1:60, 62, 64, $66,69)$. Novak ima vremena da izgradi kompletnu narativnu strukturu u relativno kratkom okviru; priča kreće od opšteg i ide ka posebnom - sve i svašta, da ti pričam do sutra, ti ljudi, njihova dobacivanja, jedna žena, njena dobacivanja - a završava se poentom (Novakov ironični odgovor). Priča se sastoji iz početna dva duža i tri kraća turnusa, a dva duža turnusa sadrže veliki broj mikropauza i udisaja (uz jedan izdisaj). Zapravo, priprema za priču počinje produženim udisajem. Čujno disanje se svakako prirodno javlja u svim dužim govornim instancama.

$\mathrm{Na}$ kraju, treba pomenuti ulogu publike u studiju. U T1 publika se aktivirala samo šest puta, uključujući i početni pozdrav prilikom predstavljanja gosta. Aktiviranje je realizovano isključivo putem aplauza, koji su uticali na iskaze govornika za vreme i neposredno posle aplauza. Primećujemo da govornici započinju svoj turnus dok se aplauz još nije stišao kako bi publici stavili do znanja da aplauz treba da utihne. Ovo je vidljivo iz ponavljanja jedinica za građenje turnusa, koje se javlja na početku turnusa za vreme i neposredno posle aplauza (T1:20, 26, 29-30, 69). Ivan čak pravi „pozorišnu“ pauzu u T1:20 jer ne može da nadjača aplauz publike. Takođe, aplauzi slede posle turnusa koji nisu humoristični, već deluju kao stvar protokola, te postoji mogućnost da su pojedini aplauzi „usiljeni“, tj. da se publici pali svetleći znak za aplauz. Kod Conana se publika aktivirala 14 puta uključujući početno pozdravljanje gosta, koje uključuje i ovacije i aplauz. Ovacije i aplauz takođe se čuju prilikom predstavljanja poštanskih marki. Ostalih 12 aktivacija publike uključuju smeh, čega u T1 nije bilo, barem ne dovoljno glasnog smeha. Smeh publike sledi posle šaljivih opaski ili anegdota. Dok Conan ciljano tera publiku na smeh, Novak to radi više spontano, kroz kooperaciju s Conanom. Nameće se zaključak da je Conan podjednako orijentisan na gosta ali i na neposredno zabavljanje publike, dok je Veče sa Ivanom Ivanovićem više orijentisano na gosta, dok publika igra protokolarnu ulogu. 


\section{Zaključak}

Od svojih početaka kao etnometodološki pristup proučavanju govora svakodnevnice, analiza konverzacije razvila se u efikasnu metodu analize diskursa uz pragmatiku i interakcijsku sociolingvistiku (Tolson, 2006: 4). Tok šou, televizijski žanr koji se razvija poslednjih 65 godina u svojoj osnovi, pa i samom nazivu, ima govor, te se analiza konverzacije prirodno nameće kao moguća metoda ispitivanja ovog žanra. S proširenjem primene analize konverzacije i na institucionalni govor, otvorio se prostor za primenu $\mathrm{u}$ analizi medijskog diskursa i njegovoj potkategoriji, analizi diskursa tok šou interakcije. Neki od autora koji su dali doprinos analizi tok šou diskursa su Andrew Tolson, Carolina Ilie, Joanna Thornborrow i Hermine Penz, kao i noviji istraživači koji su se bavili primenom analize konverzacije u proučavanju tok šou diskursa, kao što su Nadia Danileiko i Janne Carnel.

Iako tok šou govor-u-interakciji spada u kategoriju institucionalnog govora, slažemo se s konstatacijom da je ovaj tip interakcije svojevrsni spoj institucionalnog i svakodnevnog govora i da ujedinjuje sferu javnog i privatnog diskursa, te se slažemo s Ilie, koja predlaže klasifikaciju polu-institucionalni govor za tok šou interakciju. Ovo naročito važi za humoristične kasnovečernje tok šou emisije koje za cilj imaju pružanje zabave gledaocima putem ćaskanja s gostima koji su po pravilu poznate ličnosti. Poznatim ličnostima se u razgovoru pristupa familijarno, nalik govoru koji svakodnevno koristimo u interakciji s prijateljima i porodicom, s naglaskom na emotivnu, pre nego profesionalnu komponentu, što poznate ličnosti približava širokom auditorijumu i utiče na povećanje gledanosti, koje je i osnovni cilj televizije.

Primena analize konverzacije na dva odlomka tok šou razgovora u ovom radu, jednog sa srpske a drugog s američke televizije, samo je zagrebala površinu svih mogućnosti koje ova metoda može da pruži u analizi diskursa tok šou interakcije. Podrobniji zaključci nisu mogući bez značajno opsežnijeg istraživanja, koje bi podrazumevalo veći broj transkripata različitih tok šou emisija, što u začetku ograničava komparativni pristup jer je u Srbiji nedovoljno veliki izbor kasnovečernjih tok šou emisija humorističnog karaktera. U svakom slučaju, analiza konverzacije može da pruži uvid u obrasce i zakonitosti koji upravljaju tok šou interakcijom, kao i u njihove idiosinkrazijske odlike. 
Konačno, transkripcija podataka za analizu konverzacije mukotrpan je proces i oduzima dosta vremena, pa se danas taj posao radi i pomoću softverskih aplikacija kao što je, npr. Transana ${ }^{\mathrm{TM}}$, a transkripciju tok šou razgovora olakšava i činjenica da je većina emisija, odnosno intervjua s gositma, dostupna na internetu, a kombinacija video-audio zapisa omogućava detaljniju transkripciju i beleženje različitih nejezičkih prenosa poruka (setimo se da je Sacks počeo s telefonskim razgovorima, tj. samo sa zvučnim podacima, i dodajmo tome činjenicu da ljudi tokom telefonskog razgovora nesvesno prave pokrete kao da je telefonski sagovornik pored njih).

\section{Literatura}

Austin, J. L. (1962). How to do things with words. Oxford: Oxford University Press.

Carbaugh, D. (1988). Talking American: Cultural Discourses on Donahue. Norwood, NJ: Ablex Publishing Corporation.

Carnel, J. (2012). Aspects of Talk Show Interaction: The Jonathan Ross Show and The Tonight Show with JayLeno.(Neobjavljena masterteza). Ghent University, Ghent. Dostupno preko http://lib.ugent.be/fulltxt/RUG01/001/891/492/ RUG01-001891492_2012_0001_AC.pdf [19.01.2015.]

Danileiko, N. (2005). Formal and Functional Questions in an American Talk Show Late Night With Conan O'Brien. (Neobjavljena master teza). University of Jyväskylä, Jyväskylä Dostupno preko https://jyx.jyu.fi/dspace/bitstream/ handle/123456789/7405/URN_NBN_fi_jyu-2005470.pdf? sequence=1 [19.01.2015.]

Drew, Paul. (2005). Conversation analysis. In Kristine L. Fitch and Robert E. Sanders (Eds.), Handbook of language and social interaction (pp. 71-102). Mahwah: Erlbaum.

Heritage, J. (2005). Conversation analysis and institutional talk. In K. L. Fitch \& R. E. Sanders (Eds.), Handbook of language and social interaction (pp. 103-148). Mahwah: Erlbaum.

Hutchby, I. \& R. Wooffitt. (2008). Conversation Analysis. Cambridge: Polity Press.

Ilie, C. (2001). Semi-institutional discourse: The case of talk shows. Journal of Pragmatics, 33, 209-254.

Keenan, E. \& Schieffelin, B. B. (1976). Topic as a Discourse Notion: A Study of Topic in the Conversation of Children and Adults. In C. N. Li (Ed.), Subject and Topic (pp. 335-384). New York: Academic Press. 
Levinson, S.C. (1983). Pragmatics. Cambridge: Cambridge University Press. Liddicoat, A. (2007). An introduction to Conversation Analysis. London: Continuum.

McIlvenny, P. (2002). Transcription conventions. In P. McIlvenny (Ed.), Talking gender and sexuality: Conversation, performativity and discourse in interaction (pp. viii-ix). Amsterdam: John Benjamins.

Sacks, H., Schegloff, E. A., \& Jefferson, G. (1974). A simplest sytematics for the organization of turn-taking for conversation. Language, 50(4), 696-735.

Schegloff, E. (2007). Sequence organization in interaction. A primer in Conversation Analysis (volume 1). Cambridge: Cambridge University Press.

Searle, J. (1974). Speech Acts: An Essay in the Philosophy of Language. Cambridge: Cambridge University Press.

Stević, S. (1997). Analiza konverzacije. Beograd: Filološki fakultet.

Tiittula, L. \& Nuolijärvi, P. (2000). Televisiokeskustelun näyttämöllä: televisioinstitutionaalisuus suomalaisessa ja saksalaisessa keskustelukulttuurissa. Helsinki: Suomalaisen Kirjallisuuden Seura.

Tolson, A. (1991). Televised chat and the synthetic personality. In P. Scannell (Ed.), Broadcast talk (pp. 178-200). London: Sage.

Tolson, A. (2001). Introduction: the talk show phenomenon. In A. Tolson (Ed.), Television talk shows. Discourse, performance, spectacle (pp. 1-5). Mahwah: Erlbaum.

Tolson, A. (2006). Media Talk: Spoken Discourse on TV and Radio. Edinburgh: Edinburgh University Press.

Wooffitt, R. (2005). Conversation Analysis and Discourse Analysis: A Comparative and Critical Introduction. London: SAGE Publications.

\section{Izvori}

Conan (TBS, 03.08.2011.) (video zapis odlomka TV emisije). Dostupno preko https://www.youtube.com/watch?v=qX96HTP9Y10 [17.02.2015.]

Veče sa Ivanom Ivanovićem (Prva televizija, 18.02.2011.) (video zapis odlomka TV emisije). Dostupno preko https://www.youtube.com/ watch?v=lqL0WZiEJzQ [18.02.2015.] 
Predrag D. Niketić

\title{
CONVERSATION ANALYSIS AND INTERACTION IN LATE-NIGHT TELEVISION TALK SHOWS: EXAMPLES OF A SERBIAN AND AN AMERICAN SHOW
}

\begin{abstract}
Summary
This paper presented the application of conversation analysis, a method for studying human talk-in-interaction in everyday social life, in analyzing talk-ininteraction discourse in TV late night talk shows focused on celebrity interviews, whose purpose is to provide entertainment for the viewers. The analysis relied on the comparative approach and the examples used were sections of two interviews with the Serbian tennis player Novak Đoković on the Serbian talk show Veče sa Ivanom Ivanovićem (An Evening with Ivan Ivanović) and the US talk show Conan. The data for these interviews was transcribed from the video material available online. After the introduction, the second section provided a historical perspective of conversation analysis, with its original application in ethnomethodology, a branch of sociology, and its later expansion to discourse analysis. This section also touched upon the theoretical fundamentals of conversation analysis and the relevant terminology. The following section was dedicated to the description of general features of the talk show TV genre, which is categorized as a part of the public and the media discourse but which also contains features of the private discourse, or everyday casual talk. The fourth section included the list of transcription symbols used for the transcription of the said talk shows, followed by the talk show transcripts and the Serbian translation of the US talk show transcript. In the fifth chapter, the transcripts were analyzed and numerous similarities between the interviews were observed. However, the main differences involve the length of the overall interviews, which affects the conversation rhythm, and the role of the audience, primarily how much the talk show hosts pay attention to the audience. In the concluding section, it was observed that, as a type of interview, talk show interaction is considered a form of institutional talk, but that its non-institutional character is not neglected, as it relies on a type of interaction similar to everyday interaction between family and friends. Hence, the classification of talk show interaction as semi-institutional talk was accepted.
\end{abstract}

Key words: conversation analysis, discourse, talk show, talk-in-interaction, semi-institutional talk 